\title{
Hz. Peygamber'in Yahudi Bir Kadın Tarafından Zehirlenmesi Hadisesi Hakkındaki Rivayetler ve Kur'ân Dışı Vahiyle İlgisi
}

\section{Serkan Çelikan*}

Öz

Hadis ve siyer kaynaklarında Yahudi bir kadının Hayber'in fethine denk gelen günlerde Hz. Peygamber'i (s.a.v.) zehirleyerek öldürmek istediğine dair bazı rivayetler bulunmaktadır. Bu rivayetler, tespit edilebildiği kadarıyla Ebû Hureyre, Enes b. Mâlik, Câbir b. Abdillah, Ebû Lübeybe ve Ebû Saîd el-Hudrî isimli sahâbîlerden nakledilmişlerdir. Abdurrahman b. Ka'b b. Mâlik'ten nakledilen mürsel bir rivayet de bulunmaktadır. Bu rivayetlerin önemli düzeyde lafız ve muhteva farkları, ziyade ve eksik bilgiler taşıdığı görülür. Söz konusu rivayet farkları râvîlerin nakil esnasında yaptıkları bazı tasarrufların habercisi olarak görünmektedir. Bununla beraber rivayetlerin tamamı bir arada değerlendirildiğinde Hz. Peygamber'in zehirlenmesi hadisesi ile ilgili gerçekçi bir sonuca ulaşmanın mümkün olduğu anlaşılmaktadır. Diğer yandan bazı rivayetlerdeki, zehirlenmiş koyun etinin, kendisinin zehirli olduğunu haber verdiği ayrıntısı Hz. Peygamber'e gelen Kur'ân dışı vahiyle de ilişkilendirilmiştir. Reddedenler de bulunmakla birlikte Kur'ân dışı vahiy Ehl-i sünnet düşüncesinde genel olarak kabul görmüștür. Ancak Hz. Peygamber'in zehirlenmesi meselesiyle ilgili rivayetlerin Kur'ân dışı vahiy iddiasını temellendirdikleri konusu tartışmaya açık görünmektedir. $\mathrm{Bu}$ çalışmada ilgili rivayetler bir arada değerlendirilerek meselenin aslı ve Kur'ân dıșı vahiyle ilgisi belirlenmeye çalışılacaktır.

Anahtar Kelimeler: Kur'ân Dışı Vahiy, Yahudi Kadın, Zehirli Koyun Eti, Hayber Fethi, Rivayet.

\section{Accounts of the Prophet Muhammad's Being Poisoned by a Jewish}

\section{Woman and Their Connection with Non-Qur'anic Revelations}

\begin{abstract}
There are certain narratives in hadith and siyer (prophetic biography) sources of an event that a Jewish woman wanted to poison and kill the Prophet Muhammad in the days leading up to the conquest of Khaybar. These narratives, as far as can be determined were conveyed from the sahabah named Abu Hurairah, Anas b. Malik, Jabir b. 'Abdullah, Abu Lubaibah and Abu Sa'id al-Khudri. There is also a mursal narrative conveyed from 'Abdurrahman b. Ka'b b. Malik. These narratives are seen to carry significant wording and content differences, and have excess and incomplete information. These differences in accounts appear to be a harbinger of certain amendments of the narrators when they recounted the information. However,
\end{abstract}


considering all the accounts together, it is understood that it is possible to reach a realistic conclusion about the poisoning of the Prophet Muhammad. On the other hand, the detail in some of the accounts that the poisonous mutton informed its being poisonous has also been associated with a non-Qur'anic revelation revealed to the Prophet Muhammad. Although there are also those who refuse the idea, the idea of non-Qur'anic revelation has been accepted in the school of thought of Sunni Muslims in general. Nevertheless, the argument that the accounts of the poisoning of the Prophet Muhammad provide the basis for the claim of non-Quranic revelation seems open to discussion. In this study, the accounts in question will be evaluated together to determine the relationship between the essence of the matter and the non-Qur'anic revelation.

Keywords: Non-Qur'anic Revelation, Jewish Woman, Poisonous Mutton, Conquest of Khaybar, Narrative.

\section{Giriş}

Hz. Peygamber'e Kur'ân dışında vahiy gelip gelmediği meselesi erken dönemlerden itibaren tartışma konusu olmuştur. ${ }^{1}$ Daha çok sünnetin kaynağı tartışmaları bağlamında ${ }^{2}$ gündeme gelen Kur'ân dişı vahyin, Ehl-i sünnet düşüncesinde genel kabul gördüğü anlaşllmaktadır. Örneğin Mâtürîdî'nin (ö. 333/944) vahyin türleri hakkında yapmış olduğu, Kur'ân, beyân ve ilhâm/ifhâm şeklindeki üçlü taksimin üçüncü maddesinde Kur'ân dışı vahiy anlayışını görmek mümkündür. ${ }^{3}$ Şâfiî̀nin, kitap ve hikmetin indirildiğini bildiren bazı âyetler bağlamında ${ }^{4}$ bu âyetlerdeki hikmet kavramının Allah rasûlünün sünneti olarak anlaşılması gerektiği yönündeki ifadesi onun da sünnetin vahiy ürünü olduğu düşüncesine sahip olduğu şeklinde yorumlanabilir. ${ }^{5}$

Vahy-i gayr-i metlüv ${ }^{6}$ olarak da isimlendirilen Kur'ân dışı vahyin dayandırıldığı deliller söz konusu iddiayı önemli ölçüde destekler görünmektedir.

1 Hassân b. Atıyye’ye (ö. 130/748 [?]) nispet edilen “Cebrâil nebîye (s.a.v.) Kur’ân'ı indirdiği gibi sünneti de indirirdi." șeklindeki söz sünnetin kaynağının vahiy olduğu düşüncesiyle ilgili erken bir örnek olarak zikredilebilir. Bk. Dârimî, Ebû Muhammed Abdullah Abdurrahman ed-Dârimî, es-Sünen (İstanbul: Çağrı Yayınları/Dâru Sehnûn, 1413/1992), "Mukaddime", 49. Ayrıca bk. Mehmet Hayri Kırbaşoğlu, İslâm Düşüncesinde Sünnet (Ankara: Fecr Yayınları, 1993), 254. Şâfiî’nin (ö. 204/819) er-Risâle'de sünnetin mahiyeti ile ilgili olarak kendi zamanındaki bazı eğilimlerden bahsetmesi ve Kur'ân dışı vahyi temellendirme amacıyla zikrettiği anlaşılan rivayetler de tartışmanın tarihi için örnek verilebilir. Bk. Şafiî, Ebû Abdillah Muhammed b. İdrîs, er-Risâle, thk. Abdüllatif el-Hümeym, Mâhir Yâsîn el-Fahl, (Beyrut: Dâru'l-Kütübi'l-İlmiyye, 2009), 122-123.

2 Kur'ân dışı vahyin sünnetin kaynağı bağlamında kapsamlı bir şekilde değerlendirildiği ve vahyin bu türünü temellendirmek için ileri sürülen kanıtların incelendiği bir çalışma için bk. Kırbaşoğlu, İslâm Düșüncesinde Sünnet, 253-280.

3 Mâtürîdî, Ebû Mansûr Muhammed b. Muhammed, Te’vīlātü'l-Kur'ān, thk. Ahmed Vanlığlu (İstanbul: Dâru'l-Mîzân, 2005), 13/251-252.

$4 \quad$ Bakara, 2/231; Nisâ, 4/113.

5 Şafîi, er-Risāle, 111. Şâfiî̀nin sünnet-vahiy ilişkisi ile ilgili görüşlerinin kapsamlı bir değerlendirmesi için bk. Kırbaşoğlu, İslâm Düşüncesinde Sünnet, 254-258.

6 Kavramın lafız bakımdan olmasa da içerik bakımından ilk olarak Şâfiî de görüldüğü söylenebilir. Bk. Şafiî, Ebû Abdillah Muhammed b. İdrîs, el-Ümm (Beyrut: Dâru'Ma'rife, 1393), 7/299. Ayrıca bk. Kırbașoğlu, İslâm Düșüncesinde Sünnet, 253. İbn Hazm'ın (ö. 456/1064), vahyin türleri hakkında yaptığı bir taksimde de bu kavramı görmek mümkündür. Buna göre İbn Hazm, "O hevâ ve arzularına göre konuşmaz. Onun konușması sadece kendisine bildirilen bir vahiyden ibarettir." (Necm, 53/3-4) âyetini zikrettikten sonra şöyle demiștir: "Bu âyetin delaletiyle bizim 
Özellikle, namaz, oruç, hac gibi ibadetlerin yapılış şekillerinin, helaller ve haramlarla ilgili bazı meselelerin ve diğer bir kısım ahkâmın Kur'ân'da ya kendilerinin ya da tafsilatlarının bulunmuyor olması, bunların, vahyin başka bir türü ile Hz. Peygamber'e öğretildikleri tezini güçlendiren bir kanıt olarak değerlendirilebilir.7 Ancak Kur'ân dışı vahyi temellendirdiği iddia edilen bazı rivayetlerin bu iddiaya yeterli düzeyde mesnet teşkil etmedikleri de anlaşılmaktadır. ${ }^{8}$ Hz. Peygamber'in Yahudi bir kadın tarafından zehirlendiğinden bahseden rivayetler de Kur'ân dışı vahiy bağlamında zikredilen rivayetlerdendir. ${ }^{9}$

Hadis ve siyer kaynaklarında Hz. Peygamber'in (s.a.v.), Yahudi savaşçı Merhab'ın ${ }^{10}$ kız kardeşi; Sellâm b. Mişkem'in karısı Zeyneb bnt. el-Hâris isimli11 Yahudi bir kadın tarafından Hayber'de zehirli et yedirilerek öldürülmek istendiğine dair çeşitli rivayetler bulunmaktadır. Rivayetler incelendiğinde lafız ve muhteva bakımından oldukça farklı oldukları görülür. Nitekim bazı rivayetlerde bu eylem Yahudi bir kadına nispet edilirken bazılarında Yahudi bir gruba nispet edilir. Yine bir kısım rivayete göre Hz. Peygamber (s.a.v.) ve ashâbı bu kadının hediye ettiği etten yemiş, bir kısmına göre ise yememiştir. Hz. Peygamber'in, eti yedikten sonra zehirli

için doğru olan șey, Allah'ın, Rasûlüne göndermiş olduğu vahyin iki kısma ayrıldığını kabul etmektir. Bunlardan ilki Kur'ân olup, "metlüv" dür (namazlarda tilavet edilir) ve nazım/tertip bakımından mu'cizdir. İkincisi ise bize nakledilen ve nazmı/tertibi itibariyle mu'ciz olmayan, yine (namazlarda) tilavet olunmamakla birlikte başka zamanlarda okunan vahiydir ki bu da Rasûlullah'tan (s.a.v.) gelen haberdir." Bk. İbn Hazm, Ebû Muhammed Ali b. Ahmed, el-ịhkām fí ușūli'l-aḥkām, thk. Ahmed Muhammed Şâkir (Beyrut: Dâru'l-Âfâki'l-Cedîde, ts.), 1/96-97.

7 Kur'ân dıșı vahyi temellendirdiği düşünülen bazı deliller için bk. Muhammad Taqi Usmani, The Authority of Sunnah (Karachi: Idratul Quran, ts.) 23-44; Saffet Sancaklı, Hadis İnkârcıllı̆ı/Hadis Karşıtlarının İddiaları ve Cevaplar, 3. Baskı (İstanbul: Rağbet Yayınları, 2018), 212-217.

8 Kur'ân dışı vahyi temellendirdiği düşünülmekle birlikte bu konuda açı olmadıkları ve ihtiyatla yaklaşılması gerektiği ifade edilen bazı rivayetlerin incelendiği bir çalışma için bk. Bünyamin Erul, “Hz. Peygamber'e Kur'ân Dışında Vahiy Geldiğini İfade Eden Rivayetlerin Tahlil ve Tenkidi”, İslâmiyât, 1/1, 1998. 55-72. Kur'ân dışı vahiy meselesini gaybî haberler bağlamında inceleyen bir başka çalışmanın özellikle Hz. Peygamber dönemi örnekleri için bk. Mehmed Said Hatiboğlu, Hz. Peygamber ve Kur'ân Dışı Vahiy (Ankara: Otto Yayınları, 2017), 101-116.

$9 \quad$ Hz. Peygamber'in Yahudi bir kadın tarafından zehirlenmesi meselesi hakkındaki rivayetin Kur'ân dıșı vahiyle kurulan ilgisi için bk. Nevevî, Ebû Zekeriyyâ Yahyâ b. Şeref, el-Minhāc șerḥu Șahịhịi Müslim b. el-Haccāc, thk. Muhammed Beyyûmî (Kâhire: Dâru'l-Gaddi'l-Cedîd, 1429/2008), 14/157; İbn Hacer, Şihâbüddîn Ahmed b. Ali el-Askalânî, Fetḥu'l-bārī şerḥu Șaḥịhi'l-Buhāāī (Beyrut: Dâru'l-Ma'rife, 2005), 6/886; Sancaklı, Hadis Ínkârcılı̆̆ı, 215.

10 Merhab'ın Hayber savaşında Muhammed b. Mesleme tarafından öldürüldüğü nakledilmektedir. Bk. Muhammed b. İshâk, es-Sìretü'n-nebeviyye, thk. Ahmed Ferîd el-Mezîdî (Beyrut: Dâru'lKütübi'l-'İlmiyye, 1424/2004), 475; İbn Hişâm, Ebû Muhammed Abdülmelik, es-Siretü'nnebeviyye, thk. Cemâl Sâbit, Muhammed Mahmûd, Seyyid İbrahim (Kahire: Dâru'l-Hadîs, 1427/2006), 3/251.

11 Bk. Musâ b. Ukbe, el-Megāzī, thk. Muhammed Bakșîș Ebû Mâlik (el-Memleketü'l-Mağribiyye: Câmiâtu İbn Zühr, 1994), 254; İbn İshâk, es-Sìretü'n-nebeviyye, 479; Vâkıdî, Ebû Abdillah Muhammed b. Ömer, Kitābu'l-Megāzī, thk. Marsden Jones (Beyrut: Âlemu'l-Kütüb, 1966), 2/677, 679; İbn Hişâm, es-Siretü'n-nebeviyye, 3/254; Ebû Dâvûd, Süleyman b. el-Eş'as es-Sicistânî, esSünen (Kahire: Dâru İbni'l-Cevzî, 1432/2011), "Diyât", 6; Nevevî, el-Minhāc, 14/157; İbn Hacer, Fethu'l-bārī, 4/81; 5/324; 6/885; Aynî, Ebû Muhammed Bedruddîn Mahmûd b. Ahmed, 'Umdetü'lkārī șerḥu Șaḥīhi'l-Buhārī, tsh. Abdullah Mahmûd Muhammed Ömer (Beyrut: Dâru'l-Kütübi'l'İlmiyye, 1421/2001), 13/242; 15/125; Azîmâbâdî, Muhammed Şemsülhak, 'Avnu'l-ma būd șerḥu Süneni Ebī Dāvūd (Beyrut: Dâru'l-Kütübi'l-'İlmiyye, 1415), 12/179. Bu kadının, Merhab'ı́n kardeșinin kızı olduğu da nakledilmiştir. Bk. Musâ b. Ukbe, el-Megāzī, 254; İbn Hacer, Fetḥu'l-bārī, 5/324; Azîmâbâdî, 'Avnu'l-ma'būd, 12/179. 
olduğunu anladığını ve zehrin etkisinden kurtulmak için kan aldırdığını gösteren rivayetlerle birlikte buna aykırı olarak, Allah'ın adını andıktan sonra eti yemeyi önerdiğini gösteren rivayetler de vardır. Ayrıca sahâbeden bir kısmının bu zehirli et nedeniyle öldügünü gösteren rivayetler olduğu gibi sadece Bişr b. el-Berâ isimli sahâbînin öldüğünü gösteren rivayetler de bulunmaktadır. Yine bazı rivayetlerde etin, kendisinin zehirli olduğunu Hz. Peygamber'e haber verdiği ayrıntısı varken bazılarında bu ayrıntı görülmemektedir. Ayrıca kadının idam edildiğini gösteren rivayetler olduğu gibi cezalandırılmayıp affedildiğini gösteren rivayetlere de rastlanır. Bu olayın nakledildiği metinler arasında ciddi düzeyde lafız ve muhteva farklarının bulunması yanında, Kur'ân dışı vahyi desteklediği de tartışmaya açık görünmektedir. Bu çalışmada konuyla ilgili rivayetler bir arada değerlendirilerek ${ }^{12}$ hem Hz. Peygamber'in zehirlenmesi meselesinin aslı hem de ilgili rivayetlerin Kur'ân dışı vahye kanıt teşkil etmeye elverişli olup olmadıkları hususu aydınlatılmaya çalışılacaktır.

\section{Hz. Peygamber'in Yahudi Bir Kadın Tarafından Zehirlenmesiyle İlgili Rivayetler}

Hz. Peygamber'in zehirlenmesi hadisesini ihtiva eden rivayetler tespit edilebildiği kadarıyla Enes b. Mâlik, Câbir b. Abdillah, Ebû Lübeybe, Ebû Saîd el-Hudrî ve Ebû Hureyre isimli sahâbîlerden nakledilmişlerdir. Abdurrahman b. Ka'b b. Mâlik'ten nakledilen mürsel bir rivayet de bulunmaktadır. Tahric edildikleri hadis kaynaklarının kronolojik durumuna göre bu rivayetler şöyle sıralanabilir:

\subsection{Abdurrahman b. Ka'b b. Mâlik'ten Nakledilen Rivayet}

En erken kaynak olarak Ma'mer b. Râşid'in (ö. 153/770) el-Cāmi'inde yer alan bu rivayet şöyledir:

Yahudi bir kadın Hz. Peygamber'e (s.a.v.) Hayber'de, kızarmış bir koyun hediye etti. Hz. Peygamber "Bu nedir?" diye sorduğunda kadın, Hz. Peygamber sadaka malından yemediği için "Sadakadır." demekten kaçındı ve "Hediyedir." dedi. Sonra Hz. Peygamber ve ashâbı o etten yediler. Derken Hz. Peygamber "Durun." dedi ve kadına "Bu koyunu zehirledin mi?" diye sordu. Kadın "Sana kim haber verdi?" dediğinde Hz. Peygamber elindeki incik kemiğini göstererek "Bu kemik." dedi. Kadın "Evet." deyince Hz. Peygamber "Neden?" diye sordu. Kadın "İstedim ki sen bir yalanciysan insanlar senden kurtulsun. Eğer peygambersen de (bu zehir) sana zarar vermesin." dedi. Bunun üzerine Hz. Peygamber iki Bu yöntem bazı çağdaş araştırmacılar tarafından "metin inşası" olarak isimlendirilmekle birlikte
taşımış olduğu bazı problemler nedeniyle "metnin bütünleştirilmesi" şeklinde bir isim de önerilmiştir. Aynı konudaki çeşitli hadis metinlerini bir arada değerlendirip rivayetin metni ve muhtevasıyla ilgili sağlıklı bir neticeye varma çabası şeklinde özetlenebilecek olan bu yöntemin, isimlendirilmesi, problemleri, gerekçeleri, faydaları ve yapılış şekliyle ilgili kapsamlı bilgi için bk. Selçuk Coşkun, "Metin İnşâsının Teorik ve Uygulamadaki Bazı Problemleri Üzerine", Bayburt Üniversitesi Illahiyat Fakültesi Dergisi 1/1 (Haziran 2015), 47, 56, 66. 
kürek kemiğinin arasından ${ }^{13}$ kan aldırdı ve ashâbına emretti, onlar da kan aldırdılar. Ancak onlardan bazıları öldü. ${ }^{14}$

Bu rivayetin isnâdı "Abdurrezzak> Ma'mer> Zührî> Abdurrahman b. Ka'b b. Mâlik." şeklindedir. ${ }^{15}$ Meşhur sahâbî Ka'b b. Mâlik'in oğlu Abdurrahman'ın Hz. Peygamber zamanında doğmuş olmakla beraber ondan bir şey rivayet etmediği bilgisine ${ }^{16}$ göre rivayet mürsel olmaktadır. Nitekim İbn Sa'd da Abdurrahman'ı ikinci tabakaya mensup Medineli tâbiîler içerisinde zikreder. ${ }^{17}$ Anlaşıldı̆̆ı kadarıyla Abdurrahman bu rivayeti babasından veya bir başka sahâbîden nakletmiştir. Beyhakî bu sahâbînin Câbir b. Abdillah olmasını muhtemel görür.18 Nitekim söz konusu râvînin şeyhleri arasında Câbir b. Abdillah'ın ismi de geçmektedir. ${ }^{19}$ Kendisinden rivayette bulunduğu zikredilen sahâbîler içerisinde sadece Câbir'in bu rivayeti naklettiğinin bilinmesi bu ihtimali güçlendirmektedir. Diğer yandan Abdurrahman, Zührî'nin şeyhleri arasında zikredilmekle ${ }^{20}$ beraber Zührî'nin ondan bir şey işitmediği yönündeki farklı bir görüşten de bahsedilmektedir. ${ }^{21}$ Ayrıca Nesâî’nin onu Zührî̀nin şuyûhu arasında zikretmediği de söylenir. ${ }^{22} \mathrm{Bu}$ bilgiler rivayetin isnâdında ittisâlin gerçekleşmediğini göstermektedir. Ancak Ebû Dâvûd, Abdurrahman'ın babasından naklettiğinin tasrih edilmesi dışında, yine mezkûr isnâdla naklettiği, zehirlenme meselesiyle dolaylı ilgisi bulunan bir başka rivayetin sonunda isnâdın sahîh olduğunu belirtmiştir. ${ }^{23}$ Elbânî'nin değerlendirmesi de yine bu isnâdın sahîh olduğu yünündedir. ${ }^{24}$ Anlaşıldığı kadarıyla Abdurrahman ile Zührî arasındaki inkıtâ ihtimali bu âlimler tarafından dikkate alınmamış veya önemli görülmemiştir.

Bu rivayeti naklettikten sonra Ma'mer, Zührî’nin, Hz. Peygamber'i zehirleyen bu kadının sonradan Müslüman olduğunu, Rasûlullah'ın da onu serbest bıraktığını söylediğini de kaydetmiștir. ${ }^{25}$ İbn Hacer de, kadının Müslüman olduğu iddiasında

13 Hz. Peygamber'in kan aldırdı ğı yerin sol kürek kemiğinin altı olduğu bilgisi de bulunmaktadır. Bk. Vâkıdî, Kitābu'l-megāzî, 2/678.

14 Ma'mer b. Râșid Ebû Urve el-Basrî, el-Cāmic, (Abdurrezzâk es-San'ânî'nin el-Musannefi ile birlikte), thk. Habîburrahmân el-A'zamî (Pakistan: el-Meclisü'l-İlmî/Beyrut: el-Mektebu'l-İslâmî, 1403/1983), 11/28-29. Rivayet Abdurrezzak'ın el-Mușannef inde bir başka yerde daha aynı isnâd ile ve küçük lafız farklarıyla tahric edilmiştir. Bk. Abdurrezzak, Ebû Bekr b. Hemmâm es-San'ânî, el-Mușannef, thk. Habîburrahman el-A'zamî (Pakistan: el-Meclisü'l-İlmî/Beyrut: el-Mektebu'lİslâmî, 1403/1983), 6/66.

15 Ma'mer b. Râşid, el-Cāmic, $2 / 28$.

16 İbn Hacer, Şihâbüddîn Ahmed b. Ali b. Muhammed b. Ahmed el-Askalânî, Tehzīibu't-Tehzīib (Beyrut: Müessesetü'r-Risâle, 1995), 2/574.

17 İbn Sa'd, Muhammed b. Sa'd b. Meni' ez-Zührî, Kitābu'ț-țabakāāti'l-kebīr, thk. Ali Muhammed Ömer (Kahire: Mektebetü'l-Hancî, 1421/2001), 7/269.

18 Beyhakî, Ebû Bekr Ahmed b. el-Huseyn, Delāi'lü'n-nübüvve ve ma'rifetü aḥvāli șāḥibi'ş-șerī $a$, tlk. Abdulmu'tî Kal'acî (Beyrut: Dâru'l-Kütübi'l-'İlmiyye/Dâru'r-Reyyân li't-Turâs, 1408/1988), $4 / 262$.

19 Mizzî, Cemâlüddîn Ebu'l-Haccâc Yusuf, Tehżību'l-Kemāl fi esmāi'r-ricāl, thk. Beşşâr Avvâd Marûf (Beyrut: Müessesetü'r-Risâle, 1403/1983), 17/369.

Mizzî, Tehżību'l-Kemāl, 17/369; İbn Hacer, Tehzīibu't-Tehzīib, 2/547.

İbn Hacer, Tehzīibu't-Tehzīib, 2/547.

İbn Hacer, Tehżību't-Tehżīb, 2/547.

Ebû Dâvûd, "Diyât", 6.

Ebû Dâvûd, "Diyât", 6 (Muhakkikin notu).

Ma'mer b. Râşid, el-Cāmic , 2/28. 
Zührî'nin tek olmadığını belirtir. Yine İbn Hacer'in naklettiğine göre Süleyman etTeymî bu konuda kesin konuşmuş ve kadının Hz. Peygamber'i ve orada bulunanları şahit tutarak Müslüman olduğunu ve kelime-i şehâdet getirdiğini, Hz. Peygamber'in de bu nedenle onu serbest bıraktığını belirtmiştir. ${ }^{26}$ Fakat Ma'mer bu bilgiden oldukça farklı olarak, insanların, Hz. Peygamber'in onu öldürttügünü söylediklerini ifade etmiştir $\mathrm{ki}^{27}$ konuyla ilgili, ileride incelenecek olan diğer rivayetlerde bu husus açıkça görülmektedir.

Söz konusu rivayeti Taberânî de el-Mu'cemu'l-kebîr' de müntehâsı yine “Zührî> Abdurrahman b. Ka'b b. Mâlik." olmakla beraber farklı bir isnâd ve kısmî lafız farkları ile nakletmiştir. ${ }^{28}$

Erken dönem İslâm tarihi kaynaklarından Musa b. Ukbe'nin (ö. 141/758) elMegāzī'sinde kadının, Hz. Peygamber'in koyunun en çok kol ve kürek kemiği kısımlarını sevdiğini öğrendiği ve hayvanın bu iki yerine daha çok zehir koyduğu yönündeki bir ayrıntıdan da bahsedilmektedir. ${ }^{29}$ Vâkıdînnin (ö. 207/823) elMegāzī'sinde de Hz. Peygamber'in, bunu neden yaptığı șeklindeki sorusuna kadının "Babamı, amcamı ve kocamı öldürdün. Kavmime büyük zarar verdin." diyerek cevap verdiği bilgisi bulunmaktadır. ${ }^{30}$ Bir başka ayrıntı da Hz. Peygamber'in bu eti ağzına alıp çiğnediği fakat yutmayıp geri çıkardığı, beraberinde bulunan Bişr b. el-Berâ b. Ma'rûr'un ise lokmasını yuttuğu șeklindedir. ${ }^{31}$ Bundan sonra Bişr'in rengi henüz yerinden kalkmadan taylesân ${ }^{32}$ gibi -sapsarı-33 olmuştur. $^{34}$

\subsection{Ebû Hureyre'den Nakledilen Rivayetler}

Ebû Hureyre'den nakledilen bir rivayetin, Hz. Peygamber'in (s.a.v.) zehirlenmesi meselesiyle ilgili rivayetlerin genelinden bazı temel noktalarda oldukça farklı olduğu görülmektedir. İbn Ebî Şeybe'nin el-Mușannefinde "Şebâbe> Leys b. Sa'd> Saîd b. Ebî Saîd el-Makburî> Ebû Hureyre." isnadıyla tahric edilen bu rivayette

\footnotetext{
26 İbn Hacer, Fethu'l'-bārī, 5/324.

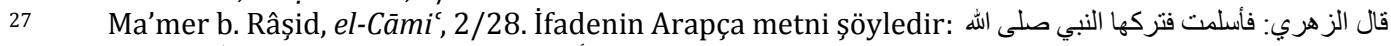
عليه وسلم ـ قال معمر : و أما الناس فيقولون: قتلها النبي صلى الله عليه وسلم Taberânî, Ebu'l-Kâsım Süleyman b. Ahmed, el-Mu'cemu'l-kebīr, thk. Hamdî b. Abdülmecîd esSelefî (Musul: Mektebetü'l-'Ulûm ve'l-Hikem, 1404/1983), 19/70. Bk. Musâ b. Ukbe, el-Megāzī, 254. Ayrıca bk. İbn İshâk, es-Siretü'n-nebeviyye, 479; Vâkıdî, Kitābu'lMegāzī, 2/677 (Vakılî rivayetinde de Hz. Peygamber'in sevdiği yerler olarak kol ve kürek kemiğinden bahsedilmekte ve yine bu rivayette kadının iki kol ve iki kürek kemiğine daha fazla zehir koyduğu bilgisi bulunmaktadır. Ancak İbn İshâk rivayeti sadece kol kısmından bahseder); İbn Hişâm, es-Siretü'n-nebeviyye, 3/254; İbn Hacer, Fetḥu'l-bārī, 5/324; Azîmâbâdî, 'Avnu'lma'būd, 12/178.

$30 \quad$ Bk. Vâkı̀î, Kitābu'l-Megāzī, 2/678; İbn Hacer, Fetḥu'l-bārī, 5/324.

31 İbn İshâk, es-Siretü'n-nebeviyye, 479; İbn Hişâm, es-Siretü'n-nebeviyye, 3/254; İbn Hacer, Fetḥu'lbārī, 5/324.

32 Taylesân bir çeşit elbisedir. Bk. İbn Manzûr, Cemalüddîn Muhammed b. Mükerrem, Lisānu'l- 'Arab, thk. Abdullah Ali el-Kebîr, Muhammed Ahmed Hasebullah, Hâşim Muhammed eş-Şâzelî, Seyyid Ramazan Ahmed (Kahire: Dâru'l-Ma'ârif, ts.), 4/2689.

33 Bu elbisenin renginin sapsarı olușu İbn Hacer'in ifadesine göredir. Bk. İbn Hacer, Fethu'l-bārī, 6/886. Bu tür elbisede siyah renge de vurgu yapıldığı görülmektedir. Bk. İbn Manzûr, Lisānu'l'Arab, 4/2689. Musâ b. Ukbe, el-Megāzī, 255; Vâkıdî, Kitābu'l-Megāzī, 2/678; İbn Hacer, Fetḥu'l-bārī, 6/886.
} 
Hayber fethedildiğinde Hz. Peygamber'e zehirli bir koyun hediye edildiği bilgisi

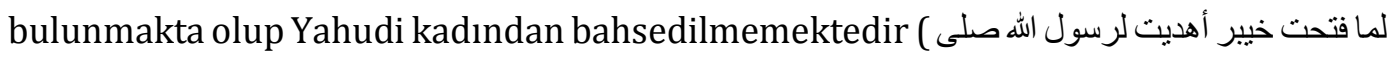
(الله عليه وسلم شاة فيها سم toplanmasını istemiş ve onlara koyunun içine zehir koyup koymadıklarını sormuştur. Onlar zehir koyduklarını söyleyince Hz. Peygamber bunu neden yaptıklarını sormuş onlar da "İstedik ki yalancıysan senden kurtulalım. Peygambersen de zaten sana zarar vermeyecekti." demişlerdir. ${ }^{36}$

Bu rivayet çeşitli kaynaklarda, Hz. Peygamber ile Yahudiler arasında geçen ve farklı konulardaki bazı soru ve cevaplardan oluşan bir konuşmayı ihtiva eden bir metinle de nakledilmiştir. ${ }^{37}$

Ebû Dâvûd'un es-Sünen'inde tahric edilen Ebû Hureyre rivayetlerinden bir diğeri oldukça muhtasardır. Buna göre Yahudi bir kadın Rasûlullah’a (s.a.v) zehirli bir koyun hediye etmiş, Rasûlullah ise kadına bu nedenle herhangi bir ceza vermemiştir. Ebû Dâvûd'un, rivayetin sonunda kaydettiği bir bilgiye göre de Hz. Peygamber'i zehirleyen bu Yahudi kadın -daha önce de geçtiği üzere- Merhab'ın kız kardeşidir. ${ }^{38}$

Ebû Hureyre'den nakledilen bir başka rivayet ise detaylı bilgi içermektedir. "Muhammed b. Sâlih b. Hâni> es-Serî b. Huzeyme> Abdülaziz b. Dâvûd el-Harrânî> Hammâd b. Seleme> Muhammed b. Amr el-Leysî> Ebû Seleme> Ebû Hureyre." isnâdlı bu rivayete göre Yahudi kadın Hz. Peygamber'i ve ashâbını kızarmış bir koyun yemeğe davet etmiştir. Onlar oturup yemeye başlayınca Rasûlullah bir lokma almış ve onu hemen geri bırakmıştır. Sonra ashâba "Bırakın! Bu koyun zehirli." demiştir. Daha sonra da kadına "Yazıklar olsun sana! Beni neden zehirledin?" demiş kadın da yukarıda kaydedilenlere benzer şekilde Hz. Peygamber'in eğer bir peygamberse zarar görmeyeceğini bilmek istediğini, değilse de insanları ondan kurtarmış olacağını söylemiştir. Yine burada da Bişr b. el-Berâ'nın etten yediği ve öldüğü $\mathrm{Hz}$. Peygamber'in de kadını öldürttüğü bilgisi yer almaktadır. ${ }^{39}$

Hâkim bu rivayetin Müslim'in şartına göre sahîh olduğunu ancak Buhârî ve Müslim'in tahric etmediklerini belirtmiş, Zehebî ise rivayet hakkında yorum yapmamıștır. ${ }^{40}$

Ebû Hureyre'den nakledilen "Zekeriyyâ b. Yahyâ es-Sâcî> İbrahim b. Saîd elCevherî> Saîd b. Muhammed el-Verrâk> Muhammed b. Amr> Ebû Seleme> Ebû Hureyre." isnâdlı bir başka rivayette ise Yahudi kadının Hz. Peygamber'e kızarmış koyun hediye ettiği, Hz. Peygamber'in bundan yedikten sonra “(Bu bana) kendisinin

\footnotetext{
35 İbn Ebî Șeybe, Ebû Bekir Abdullah b. Muhammed, el-Mușannef, thk. Muhammed Avvâme (b.y.: Dâru'l-Kıble, ts.), 12/65.

İbn Ebî Șeybe, el-Musannef, 12/65.

37 Ahmed b. Hanbel, Ebû Abdillah eş-Şeybânî, el-Müsned, thk. Şuayb el-Arnaût v.dğr. (Beyrut: Müessesetü'r-Risâle, 1416/1995), 15/513; Dârimî, "Mukaddime", 11; Buhârî, Muhammed b. İsmail, el-Cāmi u'ṣ-ṣaḥịh (Riyad: Dâru's-Selâm, 1999), “Cizye”, 7; “Tıbb”, 55.

38 Ebû Dâvûd, "Diyâtt", 6.

39 Hâkim, Muhammed b. Abdillah en-Nîsâbûrî, el-Müstedrek 'ale'ṣ-Ṣahịhaynn (Beyrut: Dâru'lKütübi'l-'ilmiyye, 1411/1990), 3/242.

40 Hâkim, el-Müstedrek, 3/242.
} 
zehirli olduğunu haber verdi." (أخبرتني أنها مسمومة) dediği bilgisi yer almaktadır. Yine bu rivayete göre de etten yiyen Bişr b. el-Berâ vefat etmiştir. Hz. Peygamber'in kadını sorgulaması ve aldığı cevaplar yukarıdaki rivayetlerle benzerlik göstermekle birlikte burada öncekilerden farklı olarak kadının "Eğer kralsan insanları senden kurtarmış olurum." (و إن كنت ملكا أرحت الناس منك) dediği görülmektedir. Yine bu rivayete göre de Hz. Peygamber'in emretmesi üzerine kadın öldürülür. ${ }^{41}$

Bu rivayet Dârimî̀nin ve Ebû Dâvûd'un es-Sünen'lerinde “Muhammed b. Amr el-Leysî> Ebû Seleme." isnâdıyla, Ebû Hureyre zikredilmeksizin mürsel olarak da nakledilmiştir. Burada ilave olarak Hz. Peygamber'in hediyeyi kabul ettiği fakat sadakayı kabul etmediği bilgileri de bulunur. ${ }^{42}$ Yine bu rivayete göre Rasûlullah "Hayber'de yediğim (zehirli) etin tesirini her zaman hissetmişimdir. İşte şu an kalp damarlarımın kesildiği andır."43 demiştir. Buhârî rivayetin bu son kısmını Kitâbu'lMegâzî'de "Hz. Peygamber'in Hastalanması ve Vefatı" isimli bab başlığı altında "Yûnus> Zührî> Urve> Âişe." isnâdıyla ve kısmen farklı lafızlarla müsned olarak da nakletmiştir. ${ }^{44} \mathrm{~Hz}$. Peygamber'in, yediği zehirli etin tesiri hakkındaki bu sözü İbn İshâk'ın es-Siretü'n-nebeviyye'sinde de yer alır. Yine bu kaynakta Müslümanların, Allah Teâlâ'nın kendisine ikram etmiş olduğu nübüvvet nimeti yanında $\mathrm{Hz}$. Peygamber'in, şehit olarak vefat ettiğine inandıkları da belirtilmektedir. 45

\subsection{Enes b. Mâlik'ten Nakledilen Rivayetler}

Hz. Peygamber'in zehirlenmesi meselesiyle ilgili Enes b. Mâlik rivayetlerinden biri Ahmed b. Hanbel'in el-Müsned'inde tahric edilmiş olup şöyledir:

Yahudi bir kadın bir ete zehir koyduktan sonra Rasûlullah'a (s.a.v.) getirdi. Rasûlullah o etten yer yemez "Bu kadın ete zehir koymuș." dedi. Ashâb "Yâ Rasûlallah! Onu öldürmeyelim mi?" deyince Hz. Peygamber "Hayır." dedi. (Hadisin râvîsi) Enes "Ben zehirlenmenin belirtilerini Rasulullah'ın (s.a.v.) damak etlerinden ${ }^{46}$ bilmeğe başlamıștım." demiştir. ${ }^{47}$

Bu rivayetin "Ravh $>$ Şu'be $>$ Hişâm b. Zeyd $>$ Enes b. Mâlik." şeklindeki isnâdı hakkında Buhârî ve Müslim'in şartlarına göre sahîh olduğu değerlendirmesi yapılmıștır. ${ }^{48}$

Taberânî, el-Mu'cemu'l-kebīr, 2/34.

Ebû Dâvûd rivayetin sadece bu kısmını Ebû Hureyre'nin zikriyle beraber müsned olarak da nakletmiștir. Bk. Ebû Dâvûd, "Diyât", 6.

Dârimî, "Mukaddime", 11; Ebû Dâvûd, "Diyât", 6.

Buhârî, "Megâzî", 84.

İbn İshâk, es-Sirretü'n-nebeviyye, 479; İbn Hişâm, es-Siretü'n-nebeviyye, 3/254.

لهاة kelimesinin "küçük dil" anlamına geldiği de söylenmektedir. Ancak bu kelime لهوات Hadisteki kelimesinin çoğulu olması ve küçük dilin de çoğulu bulunmaması bakımından "damak etleri" anlamı vermek daha uygun görünmektedir. Bu zehrin Hz. Peygamber'in damağında kararma veya bașka türlü bir etki bıraktığı ifade edilmiștir. Enes b. Mâlik'in gördüğü zehirlenme belirtilerinin bunlar olduğu anlașllmaktadır. Bk. Nevevî, el-Minhāc, 14/157; İbn Hacer, Fetḥu'l-bārī, 4/81; 6/886; Azîmâbâdî, 'Avnu'l-ma'būd, 12/179.

47 Ahmed b. Hanbel, el-Müsned, 21/15.

48 Ahmed b. Hanbel, el-Müsned, 21/15 (Muhakkikin notu). 
Buhârî'nin es-Sahîh'inde "Abdullah b. Abdilvehhâb> Hâlid b. el-Hâris> Şu'be> Hişâm b. Zeyd> Enes b. Mâlik." isnâdı ile nakledilen bir rivayet de el-Müsned'deki mezkûr rivayete benzemekle beraber ona göre daha muhtasar olduğu görülmektedir. Nitekim bu rivayette Hz. Peygamber'in, kadının ete zehir koyduğunu söylediğini gösteren cümle bulunmamaktadır. Yine burada kadının huzura getirildiği zikredilmekle birlikte el-Müsned'de bu bilgi yoktur. Enes'in ifadesi de elMüsned'dekinden farklı olarak zehrin etkisini Rasûlullah'ın damak etlerinde her zaman gördüğü yönündedir. ${ }^{49}$

Müslim'in es-Sahîh'indeki “Yayhâ b. Habîb el-Hârisî> Hâlid b. el-Hâris> Şu'be> Hişâm b. Zeyd> Enes." isnâdlı bir rivayet de yine yukarıda kaydedilen Enes rivayetlerine benzemekle beraber ilave bilgiler de içermektedir. Buna göre kadın huzura getirilmiştir ve Hz. Peygamber (s.a.v.) ona yaptığı işin sebebini sormuştur. Kadın, Rasûlullah’ı öldürmek istediği şeklindeki maksadını söyleyince Hz. Peygamber "Allah seni buna muvaffak kılmaz -veya Allah seni bana musallat etmez." demiştir. Yine Enes'in, zehrin Hz. Peygamber'deki etkisi ile ilgili sözü de Buhârî metnindeki ile aynıdır. ${ }^{50}$ Müslim bu rivayetin "Hârûn b. Abdillah> Ravh b. Ubâde> Şu'be> Hişâm b. Zeyd $>$ Enes." isnâdlı benzer bir metnine de işaret etmiştir.51 Diğer yandan Ebû Dâvûd da es-Sünen'inde rivayeti, Müslim'in isnâdının ve metninin aynısıyla tahric etmiştir. ${ }^{52}$

Enes b. Mâlik'ten nakledilen, Bezzâr'ın el-Müsned'indeki bir rivayet ise yukarıdaki rivayetlere göre oldukça farklı bilgiler içermektedir. "Muhammed b. Harb el-Vâsıtî> Yezîd b. Hârûn> Mubârek b. Fudâle> el-Hasen> Enes." isnâdlı bu rivayete göre Hz. Peygamber Yahudi kadının hediye ettiği zehirli eti yemek için elini uzattığında şöyle demiştir: "Bu koyunun uzuvlarından biri bana kendisinin zehirli olduğunu haber veriyor (إن عضوا من أعضائها يخبرني أنها مسمومة)." Bundan sonra Hz. Peygamber ve beraberindekiler o eti yemekten kaçınmışlardır. Daha sonra da Hz. Peygamber o kadını huzuruna getirtmiş ve şöyle sormuştur: "Onu güzelce yaptıktan sonra bozmaya seni sevk eden şey nedir?" Kadın bu soruya "Bilmek istedim ki sen bir peygambersen etin zehirli olduğunu bilecektin. Peygamber değilsen de insanları senden kurtarmış olacaktım." diyerek cevap vermiştir. ${ }^{53}$

\subsection{Câbir b. Abdillah'tan Nakledilen Rivayet}

Hz. Peygamber'in (s.a.v.) Yahudi bir kadın tarafından zehirlendiğini gösteren bir rivayet de Dârimî'nin es-Sünen'inde "el-Hakem b. Nâfi> Şuayb b. Ebî Hamza> Zührî> Câbir b. Abdillah." isnâdıyla tahric edilmiştir. Oldukça mufassal sayılabilecek bu rivayette Yahudi kadının Hayber halkından olduğu ayrıntısı bulunur. Yine Hz.

Buhârî, "Hibe", 28.

Müslim, Ebu'l-Huseyn Müslim b. el-Haccâc, el-Cāmi 'u'ṣ-șaḥiḥ (İstanbul: Çağrı Yay. ve Dâru Sehnûn, 1413/1992), "Selâm", 45.

Müslim, "Selâm", 45.

Ebû Dâvûd, "Diyât", 6.

Bezzâr, Ebû Bekr Ahmed b. Amr b. Abdulhâlık b. Hallâd b. Ubeydullâh el-Atekî, Müsnedu'l-Bezzār (Baḥru'z-zehhhār), thk. Mahfûzurrahmân Zeynullāh, Âdil b. Sa'd, Sabrî Abdulhâlık eş-Şâfiî (Medine: Mektebetu'l-'Ulûmi ve'l-Hikem, 1988/2009), 13/206. 
Peygamber hediye edilen koyunun kol kısmından almış ve yemiş, onunla beraber ashâbından bir grup da yemiștir. Bundan sonra Rasûlullah ashâbına "Ellerinizi çekiniz!" demiştir. Sonra da kadına birisini gönderip çağırtmış ve ona "Bu koyunu zehirledin mi?" diye sormuştur. Kadın "Evet. Sana kim haber verdi?" demiş, Rasûlullah da (elindeki) kolu göstererek "Bu, elimdeki haber verdi." demiştir. Kadın (tekrar) evet demiş, Rasûlullah "Bununla ne yapmak istedin?" dediğinde kadın "Eğer bir peygamberse ona zarar vermez. Peygamber değilse de ondan kurtulmuş oluruz dedim." demiştir. Rasûlullah da onu affetmiş ve cezalandırmamıştır. Koyundan yiyen bazı ashâbı ise vefat etmiştir. Sonra Rasûlullah koyundan yemiş olması nedeniyle iki kürek kemiği arasından kan aldırmıştır. Ondan, Beyâda oğullarının azatlısı Ebû Hind boynuz ve bıçakla kan almıştır. ${ }^{54}$

Ebû Dâvûd'un es-Sünen'indeki "Süleyman b. Dâvûd el-Mehrî> İbn Vehb> Yûnus > İbn Şihâb> Câbir b. Abdillah." isnâdlı rivayetin metninin de Dârimî'nin metni ile aynı olduğu görülmektedir. ${ }^{55}$

Mezkûr rivayetin isnâdının, Zührî'nin Câbir b. Abdillah'tan hadis işitmemiş olması nedeniyle muttasıl olmadığı söylenmiştir.56 Rivayetin Elbânî tarafından zayıf olarak değerlendirilmesi de ${ }^{57}$ yine Zührînnin Câbir'den işitmemiş olmasılyla ilgili görünmektedir. Esasen İbn Ebî Hâtim de Kitābu'l-Merāsīl'de Zührî'nin Câbir'den işitmemiş olduğunu tasrih etmiş58, Kitābu'l-cerḥi ve't-ta'dīl'de de Zührî'nin hadis işittiği sahâbîler arasında Câbir b. Abdillah'ın ismini saymamıștır. ${ }^{99}$ Ancak ricâle dair sonraki döneme ait bazı eserlerde Zührî̀nin şeyhleri arasında Câbir'in isminin de zikredildiği görülmektedir.60 Zehebî ise Zührî'nin Câbir'den işitmiş olmasını ihtimalli görür.61 Bu bilgilere göre isnâdın ittisâlinin tartışmalı olduğu söylenebilir.

\subsection{Ebû Lübeybe'den Nakledilen Rivayet}

Dârekutnî’nin es-Sünen'inde yer alan “Ahmed b. İshâk b. Behlûl> Babası (İshâk)> İbn Ebî Füdeyk> Yahyâ b. Abdirrahman b. Ebî Lübeybe> Dedesi (Ebû Lübeybe)." isnâdlı rivayette de bazı ziyadeler ve farklı bilgiler bulunmaktadır. Örneğin bu rivayette Yahudi kadının hediye ettiği bu kızartılmış zehirli koyunun Hayber gününde geldiğine vurgu yapılmıştır. Yine bu rivayete göre Rasûlullah ile beraber Bişr b. el-Berâ da bu etten yemiştir. Sonra her ikisi bu yemek nedeniyle çok ağır bir hastalık yaşamışlar daha sonra da Bişr ölmüştür. 0 öldükten sonra Rasûlullah

Dârimî, "Mukaddime”, 11.

Ebû Dâvûd, "Diyât", 6.

Hattâbî, Ebû Süleyman Hamd b. Muhammed, Me`ālimu's-sünen, tsh. Muhammed Râğıb Tabbâh (Haleb: Matbaatu'l-İlmiyye, 1352/1933), 4/7; İbn Hacer, Fetḥu'l-bārī, 5/324; Azîmâbâdî, 'Avnu'lma'būd, 12/181.

Ebû Dâvûd, "Diyât", 6 (Muhakkikin notu).

İbn Ebî Hâtim, Ebû Muhammed Abdurrahman, Kitābu'l-merāsīl, 2. Baskı, thk. Şükrullah b. Nimetillah Kûçânî (Beyrut: Müessesetü'r-Risâle, 1418/1998), 189.

59 İbn Ebî Hâtim, Ebû Muhammed Abdurrahman, Kitābu'l-cerhịi ve't-ta'dīl (Beyrut: Dâru'l-Kütübi'l'İlmiyye, 1953), 8/71.

60 Mizzî, Tehżību'l-Kemāl, 26/421; İbn Hacer, Tehżību't-Tehzīib, 3/696.

61 Zehebî, Şemsüddîn Muhammed b. Ahmed, Siyeru a'lāmi'n-nübelā, thk. Şuayb el-Arnaût, Ali Ebû Zeyd, Muhammed Nuaym el-Araksûsî (Beyrut: Müessesetü'r-Risâle, 1402/1982), 5/326. 
kadına birini gönderip getirtmiş ve ona "Yazıklar olsun sana! Bize ne yedirdin?" demiştir. Kadın da "Sana zehir yedirdim. Bilirim ki sen peygambersen bu sana zarar vermez. Allah onun durumunu sana bildirir. Eğer peygamber değilsen de istedim ki insanları senden kurtarmış olayım." demiştir. Bunun üzerine kadın, Hz. Peygamber'in emriyle asılarak idam edilmiştir.62

\subsection{Ebû Saîd el-Hudrî'den Nakledilen Rivayet}

Hâkim'in el-Müstedrek'inde Ebû Saîd el-Hudrî'den nakledilen bir rivayet ise anlaşılması zor bazı ayrıntılar içermektedir. "Ebû Ahmed Bekr b. Muhammed esSayrafî> Ebû Kılâbe er-Rakâşî Ebû Attâb Sehl b. Hammâd> Abdülmelik b. Ebî Nadra> Babası (Ebû Nadra el-Münzir b. Mâlik)> Ebû Saîd el-Hudrî." isnâdlı bu rivayete göre ashâb, Yahudi kadının hediye ettiği koyuna elini uzattığında Hz. Peygamber "Ellerinizi çekin. Bu koyunun uzuvlarından biri bana kendisinin zehirli olduğunu haber veriyor." demiştir. Rivayetin kadının sorguya çekilmesi ile ilgili bölümü yukarıdakilerle aynı muhtevada olmakla beraber sonuç bölümü oldukça farklıdır. Buna göre Hz. Peygamber kadından etin zehirli olduğunu öğrenmesine rağmen "Besmele çekiniz ve yiyiniz." (اذكرو ا اسم الله وكلو) demiştir. Ebû Saîd el-Hudrî̀nin ifadesine göre kendi de dâhil olmak üzere ashâb bu zehirli etten yemiş ve et hiç birine herhangi bir zarar vermemiştir (فأكلنا فلم يضر أحدا منا شيء).63

Konuyla ilgili rivayetler içerisinde Hz. Peygamber'in etin yenilmesine onay verdiği ve ashâbın etten yemelerine rağmen zarar görmedikleri yönündeki bilgiler, belirlenebildiği kadarıyla sadece bu rivayette bulunmaktadır ve görüldügü üzere diğer rivayetlere ciddi anlamda muhaliftir. Bununla birlikte Hâkim rivayetin isnâdının sahîh olduğunu ancak Buhârî ve Müslim'in tahric etmediklerini belirtmiş, Zehebî de rivayetin sahîh olduğu konusunda ona muvafakat etmiştir. ${ }^{64}$ Ancak râvîlerden Abdülmelik b. Ebî Nadra nedeniyle rivayetin problemli olduğu da söylenmiştir ki ${ }^{65}$ bu değerlendirme rivayetin diğer rivayetlere aykırı içeriği dikkate alındığında daha makul görünmektedir. Nitekim bu râvînin ismi erken dönem bazı ricâl edebiyatında geçmekle ${ }^{66}$ birlikte hakkında cerh ve ta'dîl yönünden herhangi bir değerlendirme yapılmamıştır ki bu onun çok tanınmadığı şeklinde yorumlanmıştır. ${ }^{67}$ İbn Hibbân'ın Sikāt'ında ve sonraki döneme ait bazı eserlerde ise bu râvînin sadûk olduğu ve zaman zaman hata yaptığı yönünde bilgiler bulunmakta olup ${ }^{68}$, yerinde bir değerlendirme olarak, bu düzeydeki bir râvînin hadislerinin aynı konudaki başka hadislere muhalif

\footnotetext{
62 Dârekutnî, es-Sünen, 4/131.

63 Hâkim, el-Müstedrek, 4/122.

64 Hâkim, el-Müstedrek, 4/122.

65 Muhammed Nâsıruddîn el-Elbânî, Silsiletü'l-ehādīsi'ż-ża īfe ve'l-mevżūa a ve eseruha's-seyyiu' fi'l'ümme (Riyad: Dâru'l-Me'ârif, 1412/1992), 13/992.

66 Muhammed b. İsmail el-Buhârî, Kitābu't-tārīhi'l-kebīr (Beyrut: Dâru'l-Kütübi'l-'İlmiyye, ts.), 5/434; İbn Ebî Hâtim, Kitābu'l-cerhi ve't-ta'dīl, 5/370/371.

67 Elbânî, Silsiletü'l-ehādīisi'ż-ża'īfe ve'l-mevżü'a, 13/992.

68 İbn Hibbân, Muhammed b. Ahmed el-Büstî, Kitābu's-sikāàt (Haydarâbâd: Müessesetü'l-Kütübi'sSekâfiyye, 1393/1973), 7/105; Mizzî, Tehżību'l-Kemāl, 18/428; İbn Hacer, Tehzīibu't-Tehzīb, 2/628; İbn Hacer, Ahmed b. Ali el-Askalânî, Takrību't-Tehzīib (Beyrut: Dâru'l-Kütübi'l-'Illmiyye, $1415 / 1995), 1 / 621$.
} 
olmadığı zaman kabul edilebileceği söylenmiştir.69 Söz konusu rivayetin diğer rivayetlere çok temel noktalarda muhalif olduğu ise gayet açıktır.

\section{Hz. Peygamber'in (s.a.v.) Zehirlenmesi Olayı İle İlgili Rivayetlerin Genel Değerlendirmesi}

Hz. Peygamber'in Yahudi bir kadın tarafından zehirlenmesi meselesiyle ilgili rivayetler görüldüğü üzere oldukça farklı ve bazen de birbirine muhalif içeriklere sahiptirler. Rivayetler arasındaki bu ihtilaflar farklı sahâbîlerden nakledilen metinler arasında bulunduğu gibi aynı sahâbîden nakledilen metinler arasında da bulunmaktadır. Bu durumdan, rivayetlerin mana ile nakledildiği ve bu süreçte râvîlerin metinler üzerinde bazı tasarruflarda bulunduğu anlaşılmaktadır. Rivayetler arasındaki, bilhassa konu bütünlüğüne ve olayın, rivayetlerin genelinden anlaşılan ve gerçekçi olarak değerlendirilebilecek oluş şekline aykırı olan farklılıkların, cerh ve ta'dîl âlimleri tarafından zayıf olarak değerlendirilen râvilerden kaynaklanmış olması kuvvetle muhtemeldir. Bu râvîlerin kimler olduğuna ve haklarında ne tür değerlendirmeler yapıldığına yeri geldikçe temas edilmiştir. Bununla birlikte genel olarak, hadis metinlerindeki tasarrufların hangi râvîden kaynaklandığının tespitinin kolay bir faaliyet olmadığı da ifade edilmelidir. Diğer yandan söz konusu ihtilafların bir kısmının cem ve te'lifinin mümkün olduğu da görülmektedir.

Rivayetler arasındaki ihtilafların te'lifine örnek olarak, Abdurrahman b. Ka'b b. Mâlik rivayetinin sonunda Ma'mer b. Râşid tarafından dile getirilen ve sonra kaydedilen bazı rivayetler arasında da görülen, Hz. Peygamber'in kadını affettiği veya öldürttüğü yönündeki ihtilafın te'lifi zikredilebilir. Bu ihtilafı giderme noktasında, koyunun zehirli olduğunu öğrendiği ilk anda, nefsi için intikam almayan biri olduğu için Rasûlullah'ın kadına ceza vermediği ancak Bişr b. el-Berâ vefat edince kadının öldürülmesini emrettiği şeklinde bir yorum bulunmaktadır.70 Buna göre her bir râvînin, şahit olduğu olayı nakletmiş olması bakımından rivayetler arasında çelişki bulunmamış olur. ${ }^{71}$ Bişr ölünce kadını Bişr'in ailesine teslim ettiği, onların da kısas olarak öldürdüğü de söylenmiştir.72 Öte yandan İbn Hacer, Hz. Peygamber'in kadını ilk başta öldürtmemesinin onun Müslüman olmasılyla ilgisini de ihtimal dâhilinde görür. Bu nedenle onun öldürülmesi, Bişr'in vefat edip kısas hükmünün tahakkukuna kadar gecikmiştir. ${ }^{73}$ Bu bilgiler ışığında kadının en nihayetinde öldürüldüğü bilgisinin

69 Elbânî, Silsiletü'l-ehādīisi'ż-ża îfe ve'l-mevżūca, 13/992.

70 Beyhakî, Ebû Bekir Ahmed b. Hüseyin, Ma'rifetü's-sünen ve'l-āsāar, thk. Abdulmu'tî Emîn Kal'acî (Karaçi: Câmiatü'd-Dirâsâti'l-İslâmiyye, v.dğr., 1412/1991), 12/51; a.mlf., Delāi'lü'n-nübüvve, 4/262-263; İbn Hacer, Fetḥu'l-bārī, 5/324; Aynî, Umdetü'l-kārī, 15/126; Azîmâbâdî, 'Avnu'lma'būd, 12/179.

71 Bk. Beyhakī, Ebû Bekir Ahmed b. Hüseyin, es-Sünenü'l-kübrā (Haydarâbâd: Meclisü Dâirati'lMa'ârifi'n-Nizâmiyye, 1344), 8/47; Azîmâbâdî, 'Avnu'l-ma'būd, 12/180.

72 Nevevî, el-Minhāc, 14/158; İbn Hacer, Fetḥu'l-bārī, 5/324; Aynî, Umdetü'l-ḳārī, 15/126; Azîmâbâdî, 'Avnu'l-ma'būd, 12/181.

73 İbn Hacer, Fethu'l-bārī, 5/324. 
doğru olduğu söylenebilir. Hatta Muhammed b. Sehnûn'a nispet edilerek, hadisçilerin Hz. Peygamber'in kadını öldürttüğü hususunda icmâsı olduğu da ifade edilmiștir. ${ }^{74}$

Yahudi kadının, zehirli etin ölüme sebebiyet vermesi sonrasında idam kararıyla veya kısasa dayalı olarak öldürüldüğü kesin görünmekle birlikte fakihler arasında bu yöntemle cinayet işlemenin hükmü tartışma konusu olmuştur. Buna göre Ebû Hanîfe'den, bir kimseyi zehir içirerek öldüren kişinin öldürülmeyeceği görüşüyle birlikte, zehrin zorla içirilmesi durumunda veya mutlak olarak diyet gerektiği görüşü de nakledilmiştir. ${ }^{75}$ Mâlik b. Enes ise bu kimselere kısas gerektiği kanaatindedir. ${ }^{76}$ Şâfiî iki görüşünden birinde bir kimsenin yiyeceğine veya içeceğine zehir koyup bunların zehirli olduğunu ona bildirmeden yediren ve içiren kimse hakkında kısası gerekli görür. Yine ondan, bir kimse yemeğe zehir karıștırıp, yenilmesini önermeksizin ortaya koyarsa ve diğer bir kimse de bundan yiyip içtikten sonra ölürse kısas gerekmediği görüşü de nakledilmiştir.77 İbn Hacer söz konusu rivayetin kısas gerektiği görüşünde olanlar için delil olduğu kanaatindedir. ${ }^{78}$ Anlaşıldığı kadarıyla bu ihtilafın temelinde zehrin tam bir öldürme aracı olarak değerlendirilmemesi bulunmaktadır. Nitekim zehir ve benzeri maddelerin bizatihi tesirinin olmadığ belirtilmiş, bunların etkisi Allah'ın izniyle ve iradesiyle ilişkilendirilmiştir.79 Dolayısıyla bu bakış açısına göre zehirli yiyecek veya içeceklerle yapılan saldırıların öldürmeye tam teşebbüs olarak değerlendirilmediği anlaşılmaktadır. Bu ayrıntının, Hz. Peygamber'in, kadını ilk anda öldürtmemesini de izah ettiği düşünülebilir.

Abdurrahman b. Ka'b ve Câbir b Abdillah'tan nakledilen rivayetlerde vefat eden sahâbî sayısının birden fazla olduğu görülürken bazı rivayetlerde sadece Bişr'nın vefat ettiği bilgisinin bulunması da ilk bakışta rivayetler arasında muhalefet olduğunu akla getirir. Ancak bu olayda esasen birden çok sahâbînin vefat ettiği, bununla beraber rivayetlerin bir kısmında sadece Bişr'in vefat ettiğinden bahsedildiği düşünüldüğünde ortada gerçek bir muhalefetin olmadığı da söylenebilir.

Rivayetlerin genelinde, Hz. Peygamber'i öldürmeye teşebbüs edenin Yahudi bir kadın olduğu bilgisi bulunmaktadır. Ebû Hureyre'den, Saîd b. Ebî Saîd el-Makburî yoluyla nakledilen rivayet ise, eylemin Yahudi bir grup tarafından yapıldığını göstermektedir. Bu durum da ilk anda rivayetler arasında ihtilaf olduğu izlenimini uyandırmakla birlikte te'lifi mümkün görünmektedir. Buna göre Yahudi ileri gelenlerinin Hz. Peygamber'i öldürtme kararı aldıkları ve bunu uygulaması için söz konusu kadını görevlendirdikleri düşünüldüğünde çelişki ihtimali ortadan kalkmış olur. Nitekim bu kadının, kullanacağı zehir hakkında Yahudi ileri gelenleriyle istișare ettiği ve neticede etkili bir zehir üzerinde görüş birliğine vardıkları yönündeki bilgi

Nevevî, el-Minhāc, 14/158; Aynî, Umdetü'l-kārrī, 15/126; Azîmâbâdî, 'Avnu'l-ma 'būd, 12/180. İbn Hacer, Muhammed b. Sehnûn'un bu görüşünü garip bulur. Bk. İbn Hacer, Fetḥu'l-bārī, 6/885.

75 Hattâbî, Me álimu's-sünen, 4/7. Ayrıca bk. İbn Hacer, Fethu'l-bārī, 6/886.

76 Hattâbî, Me âlimu's-sünen, $4 / 7$.

77 Hattâbî, Me'ālimu's-sünen, 4/7; Azîmâbâdî, 'Avnu'l-ma'būd, 12/182. Konuyla ilgili kapsamlı bilgi için bk. Vehbe Zuhaylî, el-Fikhu'l-İslāmī ve edilletuhū (Dımașk: Dâru'l-Fikr, 1405/1985), 6/243.

78 İbn Hacer, Fethu'l-bārī, 6/886.

79 İbn Hacer, Fethu'l'-bārī, 6/886. 
de ${ }^{80}$ onun bu eylemi tek başına yapmadığını göstermesi bakımından önemlidir. Rivayetlerin bazılarında Yahudi grubun bazılarında da Yahudi kadının Hz. Peygamber tarafından sorgulandıklarını gösteren ifadeler de bunların farklı zamanlarda sorgulandıkları şeklinde anlaşılabilir. Bu bakımdan mezkûr farklılık bir çelişki konusu olmamaktadır.

Yahudi kadının olaydan sonra Müslüman olduğu yönündeki bilgi ise rivayetlerde yer almaması nedeniyle kabul edilebilir görünmemektedir. Esasen Zührî tarafından yapılan bir değerlendirme olduğu hissini veren bu iddiada, İbn Hacer onun yalnız olmadığını belirtse de kendisini destekleyecek sağlam bir kanıtın bulunmadığı görülmektedir. Nitekim Ma'mer b. Râşid, Zührî’nin bu ifadesini kaydettikten sonra âlimlerin kadının öldürüldüğünü söylediklerini de belirtmiştir ki bu, onun Zührî ile hemfikir olmadığı ve bu iddiasında çoğunluğa muhalif kaldığını düşündüğü şeklinde yorumlanabilir.

Ebû Hureyre'den "Hammâd b. Seleme> Muhammed b. Amr el-Leysî> Ebû Seleme> Ebû Hureyre." tariki ile nakledilen rivayette ise diğer rivayetlerde bulunmayan bir ayrıntı görülmektedir ki bu bir râvî tasarrufuna işaret etmektedir. Buna göre Yahudi kadın Hz. Peygamber'i ve ashâbını yemeğe davet etmiştir. Oysa rivayetlerde esas olan, kadının bu eti Hz. Peygamber'e hediye ettiği veya getirdiğidir ki onun Rasûlullah'ın huzuruna gitmiş olmasını gerektirir. Nitekim "Şu'be> Hişâm b. Zeyd> Enes b. Mâlik." isnâdlı rivayetlerde kadının bu eti getirdiği tasrih edilmiştir. Vâkıdînnin el-Megāzì'sinde ise konuyla ilgili tafsilat da bulunmaktadır. Buna göre Hz. Peygamber güneş battıktan sonra akşam namazını kıldırıp konakladığı yere döndügünde Zeyneb'i orada oturur vaziyette bulmuştur. Hz. Peygamber'in sorması üzerine de Zeyneb (elindeki zehirli yemeği kastederek) "Ey Ebu'l-Kâsım! Bu sana hediyemdir." demiştir. Sonra Rasûlullah'ın emretmesiyle yemek ondan alınmış ve Hz. Peygamber'in önüne konulmuştur. Sonra da Hz. Peygamber orada bulunan ashâbına, yaklaşmalarını ve yemelerini söylemiştir. ${ }^{81} \mathrm{Bu}$ bilgiler hadis kaynaklarındaki diğer bilgilerle bir arada düşünüldügünde Hz. Peygamber'in yemeğe davet edilmediği bilakis yemeğin ona götürüldügü hususu netlik kazanmış olur. Dolayısıyla yemeğe davet ayrıntısını bir râvî yanılgısı olarak değerlendirmek mümkündür. Bu noktada akla ilk gelen râvî Muhammed b. Amr el-Leysî'dir. Nitekim bu râvînin sika olduğu da söylenmekle birlikte hadisinin sağlam olmadığı ve zaman zaman hata yaptığı yönünde değerlendirmeler bulunmaktadır. ${ }^{82}$

Savaş ortamında Hz. Peygamber'in düşman tarafından ikram edilen bir yemeği kabul edip yemesi de anlaşılması zor bir husustur. Üstelik bu düşman Yahudiler gibi, türlü entrikaları ve antlaşmalara sadakatsizlikleri o zamana kadar defalarca görülmüş bir toplum olunca Rasûlullah'ın (s.a.v.) bu tutumunu anlamak

Vâkıdî, Kitābu'l-Megāzī, 2/677.

Vâkıdî, Kitābu'l-Megāzī, 2/677.

İbn Hacer, Tehzīibu't-Tehzīib, 3/663. 
daha da zorlaşmaktadır. Kanaatimizce bu meselenin, Müslüman'a mahsus hüsn-i zan ahlakından başka kabul edilebilir bir izah tarzı bulunmamaktadır.

Rivayetlerin mana ile nakledildiklerini ve bazı râvî tasarruflarına maruz kaldıklarını göstermeleri bakımından, müntehâları "Şu'be> Hişâm b. Zeyd $>$ Enes b. Mâlik." olan isnâdlarla nakledilen rivayetler de dikkat çekicidir. Nitekim bu rivayetlerde çeşitli lafız farkları, ihtisar ve tafsil örnekleri bulunduğu ortadadır. Ancak bu râvî tasarruflarının, zehirlenme hadisesiyle ilgili rivayetlerin genel muhtevasına aykırı bir içerik ortaya koymadıkları görülmektedir. Ne var ki Bezzâr'ın elMüsned'inde, yine Enes b. Mâlik'ten nakledilen rivayette geçen, Hz. Peygamber ve beraberindekilerin o eti yemekten kaçındıkları yönündeki ayrıntının konuyla ilgili diğer rivayetlerin genel muhtevasıyla uyuşmadığı ve daha köklü bir râvî tasarrufunu haber verdiği anlaşılmaktadır. Nitekim rivayetlerin bazılarında Hz. Peygamber'in, bazılarında da ashâbın etten yedikleri tasrih edilmiştir. Hatta bu nedenle vefat eden sahâbîlerin dahi bulunduğu bilinmektedir. Diğer yandan Hz. Peygamber, uzun zaman sonra ${ }^{83}$ bile Hayber'de yediği bu etin tesirini hissettiğini söylemiştir. Esasen Bezzâr da, Yezîd b. Hârûn'un Mubârek b. Fudâle'den nakli dışında bașka nakleden bilmiyoruz demek suretiyle rivayetin garîb olduğuna işaret etmiştir. ${ }^{84}$ Bu râvîlerden Mubârek, sika olduğu da söylenmekle birlikte hakkında, zayıf olduğu ve çok tedlis yaptığı yönünde değerlendirmeler bulunan bir râvîdir. ${ }^{85}$ Dolayısıyla rivayetlerin geneliyle uyuşmayan mezkûr farklılığın bu râvîden kaynaklanmış olması ihtimal dâhilinde görülebilir. Ayrıca bu bilgiler rivayetin sıhhat değerini düşürmesi bakımından da önemlidir.

Ebû Lübeybe'den nakledilen rivayetin ise konuyla ilgili diğer rivayetlere göre farklı lafızlar ve kısmen farklı içerik taşımakla birlikte muhtevasının rivayetlerin ortak muhtevası ile telifi mümkün olmayacak bir çelişki barındırmadığı söylenebilir. Ne var ki bu rivayette geçen, zehirli etin yenilmesinin hemen akabinde Bişr'in yaşadığ ağır rahatsızlık onun sonradan vefat etmiş olması bakımından anlaşılır bir durum olmakla beraber Hz. Peygamber'in (s.a.v.) yine yemeğin hemen sonrasında ağır bir rahatsızlık geçirdiği ayrıntısı görüldüğü kadarıyla sadece bu rivayette yer almakta olup vakıaya uygun görünmemektedir. Anlaşıldığı kadarıyla bu noktada doğru olan zehrin kısa vadede değil uzun vadede Hz. Peygamber'e etki ettiğidir ki bunun damak etlerinden fark edildiği hususu Enes b. Mâlik rivayetinde geçmişti. Hz. Peygamber'in zehrin ağır etkisini uzun zaman sonra vefatı ile neticelenen hastalığı esnasında hissettiği ve dile getirdiği bilgisi de ${ }^{86}$ bu ihtimali güçlendirmektedir. Diğer yandan Hz. Peygamber'in eti çiğnediği fakat yutmadığı ayrıntısı da zehrin ona anında değil çok sonra tesir etmiş olmasıyla uyumlu görünmektedir. Ebû Lübeybe rivayetinde yer alan bir başka farklı bilgi de kadının asılarak idam edildiğidir. Bu ayrıntı diğer rivayetlerde

\footnotetext{
83 Hayber savaşının 7. Hicrî yıla gerçekleștiği, Hz. Peygamber'in de 11. Hicrî yılda vefat ettiği bilgileri dikkate alındığında onun bu olaydan sonra dört yıl yaşadığı sonucuna varılır. Bezzâr, el-Müsned, 13/206.

İbn Hacer, Tehzīibu't-Tehzīib, 4/19.

Dârimî, "Mukaddime”, 11; Buhârî, "Megâzî”, 84; Ebû Dâvûd, "Diyât", 6.
} 
bulunmamakla birlikte onların bir açıklaması olarak görülebilecek olması bakımından rivayetler arasında bir muhalefet durumu olmadığı söylenebilir.

Ebû Saîd el-Hudrî'den nakledilen rivayetteki, Hz. Peygamber'in etin zehirli olduğunu öğrenmesine rağmen "Besmele çekip yiyiniz!" dediği yönündeki bilgi, Rasûlullah'ın hadiselerin maddî sebepleri karşısındaki genel tavrıyla uyumlu görünmemektedir. Nitekim Hz. Peygamber'in hayatında, somut tedbirleri dikkate aldığını gösteren birçok örnek bulunmaktadır. Özellikle hicret esnasında aldığı tedbirler ${ }^{87}$ ve yapmış olduğu savaşlarda harp sanatına verdiği önem ${ }^{88}$ bunun önemli örnekleri olarak zikredilebilir. Diğer yandan bu rivayete göre, Hz. Peygamber'in etin zehirli olduğunu fark ettikten sonra “Ellerinizi çekin!” demesi gayet doğal ve anlaşılabilir bir tutumken daha sonra "Allah'ın ismini anıp yiyiniz!" demiş olması bu ilk tutum ile bağdaşır görünmemektedir. Ayrıca söz konusu rivayetin, diğer rivayetlerle, Hz. Peygamber'in ve ashâbın hediye edilen etten ilk anda yediği noktasında da uyuşmadığı görülmektedir. Nitekim bu rivayete göre zehirli et, kadının sorgusundan sonra yenilmiştir. Oysa diğer rivayetlerde Hz. Peygamber ve ashâbı etten yedikten sonra zehirli olduğu fark edilmiş ve kadın huzura getirilip sorgulanmıştır ki bu daha makul görünmektedir. Öte yandan Hz. Peygamber'in etin zehirli olduğunu öğrendikten sonra kan aldırdığını gösteren rivayetler de onun, zehrin tesirini yok etmeye dönük maddî/sıhhî bir tedbire başvurduğunu ortaya koyması bakımından önemlidir. Rasûlullah'ın tedaviyi öngören bu makul tavrı, zehre meydan okuyan söz konusu tavırla uygun düşmemektedir.

\section{Hz. Peygamber'in (s.a.v.) Zehirlenmesi Olayı İle İlgili Rivayetlerin Kur'ân Dışı Vahiyle İlgisi}

Hz. Peygamber'in Yahudi bir kadın tarafından zehirlenmesi meselesiyle ilgili rivayetler bazı âlimler tarafından, harikulade bir muhtevaya sahip olarak görülmüş ve Rasûlullah'a, Kur'ân haricinde de vahiy geldiğinin bir göstergesi olarak değerlendirilmiştir. Örneğin Hz. Peygamber'in etin zehirli olduğunu fark etme şekliyle ilgili olarak, Dârimî'nin konu hakkındaki rivayetleri kaydettiği “Allah Teâlâ'nın, Ölü/Cansız Varlıkları Konuşturmak Suretiyle Hz. Peygamber'e İkrâmı"89 isimli bap başlığı dikkat çekicidir. Buna göre Dârimî, rivayetlerde bahsedilen olayın mucizevî boyutu olduğunu düşünmektedir. Ayrıca Beyhakî’nin de, zehirlenme meselesiyle ilgili rivayetleri kaydetmiş olduğu bap başlı̆̆ında olayın harikulade yönüne vurgu yaptığı görülmektedir. ${ }^{90}$

Diğer yandan Nevevî "Allah seni insanlardan koruyacaktır." 91 âyetiyle de ilişkilendirerek bu rivayetin, Hz. Peygamber'in (s.a.v.) insanların tamamından korunacağının bir göstergesi olduğunu söylemiștir. Yine Nevevî'nin ifadesine göre

Bk. İbn Hişâm, es-Sìretü'n-nebeviyye, 2/354-355.

Bk. İbn İshâk, es-Sìretü'n-nebeviyye, 334; İbn Hişâm, es-Siretü'n-nebeviyye, 3/22.

Dârimî, "Mukaddime", 11.

Bk. Beyhakî, Delāi’lü'n-nübüvve, 4/256.

Mâide 5/67. 
rivayet, Hz. Peygamber'in, başka insanları öldürecek kuvvetteki zehirlerden etkilenmediğini, Allah Teâlâ'nın o koyunun zehirli olduğunu kendisine bildirdiğini ve koyunun bir uzvunun Hz. Peygamber'le konuştuğunu göstermesi bakımından Rasûlullah'ın bir mucizesidir. Nevevî özellikle son zikredilen mucize ile ilgili olarak yukarıda kaydedilen rivayetlerde geçen "Bu koyunun uzuvlarından biri bana kendisinin zehirli olduğunu haber veriyor." ifadesine de gönderme yapmıștır.92 Konuyla ilgili olarak İbn Hacer'in yaptığı değerlendirmeler de aynı istikamettedir. Nitekim o da Hz. Peygamber'e koyunun zehirli oluşunun gaybdan haber verildiğini ve cansız varlıkların onunla konuşturulduğunu belirterek olayın gaybî haber boyutuna ve mucizevî mahiyetine işaret etmiştir. ${ }^{93}$

Âlimlerin, Hz. Peygamber'in etin zehirli oluşunu öğrenmesinin olağanüstü boyutuna ve gaybî bilgi/haber yönüne yaptıkları vurguyla birlikte rivayetlerin genel ifadelerinden bu zehirli koyunun dile gelip konuştuğu şeklinde bir anlam çıkarmak tartışmaya açık görünmektedir. Bu anlamın çıkarıldığı, "Koyun bana kendisinin zehirli olduğunu haber veriyor." ifadesinin birçok rivayette bulunmaması bir yana bulunduğu rivayetlerin farklı anlașılması da imkân dâhilindedir. Nitekim Ma'mer b. Râşid'in el-Cāmi' indeki, Abdurrahman b. Ka'b'dan nakledilen rivayette kadının "Bunu sana kim haber verdi?" şeklindeki sorusuna Hz. Peygamber'in, sadece elindeki incik kemiğini göstererek "Bu kemik." diyerek cevap verdiği bilgisi bulunmaktadır. Diğer rivayetlerde ise Hz. Peygamber'in etin zehirli oluş keyfiyetini bildirirken kullandığı nakledilen kelimenin "ihbâr" kelimesi olduğu görülmekte olup bu kelimenin hayvanın bir uzvunun zehirli olduğunun anlaşılmasını sağlayacak bazı maddî emareler yoluyla verilen bir habere de işaret etmesi mümkün görünmektedir. Nitekim Câbir b. Abdillah'tan ve Abdurrahman b. Ka'b'dan nakledilen rivayetlere göre Hz. Peygamber eti yedikten sonra onun zehirli olduğunu söylemiştir ki bu, etin tadındaki değişimle ilgili olarak gayet anlaşllabilir bir durumdur. Esasen Hz. Peygamber'in, eti yedikten sonra etin dile gelip kendisinin zehirli olduğunu söylemesi de anlamlı görünmemektedir. Şayet Hz. Peygamber mucizevî bir şekilde korunacaktıysa bunun zehirli eti yemeden önce olması gerektiği hususu izaha muhtaç değildir. Bu noktada Musâ b. Ukbe'nin ve Vâkıdî'nin el-Megāzī’lerinde yer alan bir bilgi de oldukça önemlidir. Buna göre Hz. Peygamber "Ellerinizi çekin! Gerçekten bu kürek kemiği/kol bana kendisinin zehirli olduğunu haber veriyor." dediğinde Bişr b. el-Berâ "Ey Allah'ın Rasûlü! Vallahi yemiş olduğum lokmamda bunu ben de hissettim. Fakat sen yemek yerken keyfini kaçırmamak için bunu söylemek istemedim..." ${ }^{94}$ demiştir. Bişr'in bu sözünden, yemeğin tadında zehirli olduğunu gösteren bir emare olduğu anlaşılmaktadır. Dolayısıyla Hz. Peygamber'in de bu emareye göre etin zehirli olduğunu anlamış olması ve bunu "Bu et bana kendisinin zehirli olduğunu haber veriyor." cümlesi ile ifade etmesi oldukça makuldür. Kısa bir süre ve mahdut bir çevre

\footnotetext{
92 Nevevî, el-Minhāc, 14/157. Ayrıca bk. Azîmâbâdî, 'Avnu'l-ma'būd, 12/178. Nevevî'nin kaydettiği ifade إن الذراع تخبرني أنها مسمومة-șeklinde olmakla beraber hadis kaynaklarında bu șekliyle bulunmadı̆̆ı görülmektedir.

93 İbn Hacer, Fethu'l-bārī, 6/886

94 Musa b. Ukbe, el-Megāzī, 255; Vâkıdî, Kitāăbu'l-Megāzī, 2/678.
} 
içerisinde gelişen bu olayda Hz. Peygamber'in etin zehirli oluşunu fark etmesinin kaynağı ile ilgili en uygun değerlendirmenin bu olduğu kanaatindeyiz. Ayrıca hadis ve siyer musannefâtında, Hz. Peygamber'in söz konusu bilgiye ulaşma şeklini doğrudan ve net bir șekilde ortaya koyan bir başka rivayet de görüldüğü kadarıyla bulunmamaktadır.

Diğer yandan etin, kendisinin zehirli olduğunu haber verdiği bilgisini içeren rivayetlerin sshhat durumlarıyla ilgili olarak yapılan değerlendirmeler de dikkatlerden kaçmamalıdır. Nitekim bu rivayetlerden Enes b. Mâlik'ten nakledilenin garîb olduğu ve isnâdında zayıf olarak da nitelendirilen Mubârek b. Fudâle isimli bir râvî bulunduğu yukarıda kaydedilmişti. Esasen bir rivayetin garîb oluşu her zaman zayıf olduğu anlamına gelmese de, konuyla ilgili diğer rivayetlere önemli düzeyde muhalefet içermesi ve zayıf râvîlerden nakledilmiş olması bu rivayetin zayıf olduğuna hükmetmek için yeterli hususlardır. Yine Câbir b. Abdillah'tan nakledilen rivayetin de Zührî ile Câbir arasındaki kopukluk nedeniyle zayıf olarak değerlendirildiği belirlenmişti. Ebû Saîd el-Hudrî'den nakledilen rivayette de koyunun bir uzvunun kendisinin zehirli olduğunu haber verdiği geçmektedir ki bu rivayetin, etin zehirli olduğu ortaya çıktıktan sonra Hz. Peygamber'in besmele çektikten sonra yemeyi önerdiğini gösteren muhtevasıyla oldukça problemli göründügü ve râvîlerden Abdülmelik b. Ebî Nadra nedeniyle de eleștirildiği ifade edilmişti. Ayrıca, etin kendisinin zehirli olduğunu söylediği ayrıntısının, Ebû Hureyre'den nakledilen ve isnâdlarının müntehâları "Muhammed b. Amr> Ebû Seleme> Ebû Hureyre." şeklinde olan iki mufassal rivayetten sadece birinde bulunuyor olması da dikkat çekicidir. $\mathrm{Bu}$ noktada söz konusu ayrıntının yer aldığı metni Muhammed b. Amr'dan nakleden Saîd b. Muhammed el-Verrâk hakkındaki, zayıf ve metrûk olduğu, hadisinin bir değer ifade etmediği, kavî olmadığı, rivayetlerinden kaçınılması gereken kimseler arasında zikredildiği yönündeki değerlendirmelerin ${ }^{95}$ rivayeti zayıf hale getirdiği görülmektedir. Bu ayrıntının olmadığı metni Muhammed b. Amr'dan nakleden râvî ise Hammâd b. Seleme olup hakkında ta'dîle delalet eden birçok değerlendirme bulunur. Örneğin kendisinin sika, hâfız, me'mûn olduğu söylenmiştir. Hatta onun için "esbetü'n-nâs" gibi birinci dereceden ta'dîl ifadeleri de kullanılmıştır. ${ }^{96}$ Dolayısıyla Ebû Hureyre'den nakledilen bu iki rivayetten tercihe şayan olanın, etin, kendisinin zehirli olduğunu bildirdiği ayrıntısını içermeyen rivayet olduğu söylenebilir.

\section{Sonuç}

Hz. Peygamber'in (s.a.v.) Yahudi bir kadın tarafından zehirlenmesi olayından bahseden rivayetler farklı lafız ve içeriklerle nakledilmiş olsa da rivayetlerin tamamı dikkate alınarak olayın nasıl gerçekleştiği hakkında gerçekçi bir sonuca varmak mümkün görünmektedir. Buna göre Yahudiler Hayber'in fethinden sonra $\mathrm{Hz}$.

\footnotetext{
95 Mizzî, Tehzīibu'l-Kemāl, 11/48-50; İbn Hacer, Tehzīibu't-Tehzīib, 2/40; a.mlf., Taknrību't-Tehzīib, $1 / 363$.

96 Mizzî, Tehżību'l-Kemāl, 7/259-264; İbn Hacer, Tehżību't-Tehz̄īb, 1/481-483; a.mlf., Taḳību'tTehzīb, 1/238.
} 
Peygamber'i öldürme kararı almışlar ve bunun için Zeyneb bnt. el-Hâris isimli Yahudi bir kadını görevlendirmişlerdir. Kadın, Yahudi ileri gelenleriyle de istişare ettikten sonra kızarmış bir koyunu zehirleyip Hz. Peygamber'e hediye ederek onun öldürülme emrini gerçekleştirmek istemiştir. Hz. Peygamber kadının hediyesini kabul etmiş ve bazı ashâbıyla beraber bu etten yemiştir. Çiğnediği ancak yutmadığı ilk anda Hz. Peygamber, tadındaki bozulma nedeniyle etin zehirli olduğunu fark etmiş ve ashâbını ikaz etmiştir. Fakat eti yuttuğu anlaşlan Bişr b. el-Berâ, zehrin etkisiyle olaydan bir süre sonra vefat etmiştir. Berâ henüz hayattayken Hz. Peygamber kadını sorguya çekmiş ve yaptığı işi ne maksatla yaptığını öğrenmek istemiştir. Kadının, Hz. Peygamber'in gerçek bir peygamber olup olmadığını deneme yönündeki cevabı ve henüz bir can kaybı da yaşanmaması nedeniyle Rasûlullah onu cezalandırmamıştır. Ancak Bişr'nın vefatıyla kısas hakkı doğduğu için Bişr'nın ailesinin kararıyla kadını idam ettirmiştir. Çiğnemekle birlikte yutmaması, zehirli etin Hz. Peygamber'deki ölümcül tesirinin uzun vadede ortaya çıkmasına neden olmuştur. Ancak Hz. Peygamber'in ağzının iç kısmındaki bazı renk değişiklikleri zehrin ona ilk anda da etki ettiğini göstermektedir.

Henüz vefat olayı olmasa dahi kendisini öldürmeye teşebbüs eden Yahudi bir kadını Hz. Peygamber'in (s.a.v.) cezalandırmamış olması dikkat çekicidir. Hz. Peygamber'in bu tutumu kanaatimizce onun affedici oluşuyla ve intikam duygusundan uzak kişiliğiyle izah edilebilir. Diğer yandan zehirli etle cinayete teşebbüs Hz. Peygamber tarafından, öldürmeye tam teşebbüs olarak değerlendirilmediği için de kadın ilk başta cezalandırılmamış olabilir. Ancak bu teşebbüsün neticesinde Bişr b. el-Berâ'nın vefatıyla bir can kaybının ortaya çıkması maktulün ailesi için kısas hakkı doğurmuş ve kadın onların talebi üzerine idam edilmiştir. Kadının, Hz. Peygamber'in sorgusundan sonra Müslüman olduğu ve bu nedenle bağışlandığı iddiası ise sağlam bir temelden yoksun görünmektedir.

Allah Teâlâ'nın kudreti açısından imkân dışı bir şeyin bulunması mümkün değildir. Yine Allah ile Rasûlü arasında, Kur'ân dışındaki bir iletişim de mutlak manada imkânsız görülmemelidir. Ancak Hz. Peygamber'in Yahudi bir kadın tarafından zehirlenmesi meselesiyle ilgili rivayetlerin genel durumları bakımından olayın fevkalade bir mahiyetinin bulunmadığı ve her şeyin tabi seyri içerisinde cereyan ettiği hususu daha kabul edilebilir görünmektedir. Dolayısıyla bu hadisede Hz. Peygamber'e Kur'ân dışında da vahiy geldiği veya ona gaybî haber/bilgi verildiği iddiasını destekleyecek bir içerik bulunmadı̆̆ı söylenebilir.

Diğer yandan Hz. Peygamber'in hissî mucizeleriyle de ilgili olduğu görülen söz konusu rivayetlerin incelenmesiyle elde edilen neticeyi, hissî mucizelerin imkânı meselesine genelleme taraftarı olmadığımız da belirtilmelidir. Kanaatimizce hissî mucizeler meselesi kendi özelinde incelenmesi gereken diğer bir meseledir.

\section{Kaynakça}

Abdurrezzâk, Ebû Bekr b. Hemmâm es-San'ânî. el-Mușannef. 11 Cilt. Thk. Habîburrahman elA'zamî. Pakistan: el-Meclisü'l-i̇lmî/Beyrut: el-Mektebu'l-İslâmî, 2. Baskı, 1403/1983. 
Ahmed b. Hanbel, Ebû Abdillah eş-Şeybânî. el-Müsned. 50 Cilt. Thk. Şuayb el-Arnaût v.dğr. Beyrut: Müessesetü'r-Risâle, 1. Baskı, 1416/1995.

Aynî, Ebû Muhammed Bedruddîn Mahmûd b. Ahmed. 'Umdetü'l-ḳārī şerḥu Șaḥihhi'l-Buhāāī. 25 Cilt. Tsh. Abdullah Mahmûd Muhammed Ömer. Beyrut: Dâru'l-Kütübi'l-'ilmiyye, 1. Baskl, 1421/2001.

Azîmâbâdî, Muhammed Şemsülhak. 'Avnu'l-ma'būd şerḥu Süneni Ebī Dāvūd. 14 Cilt. Beyrut: Dâru'l-Kütübi'l-'illmiyye, 1. Baskı, 1415.

Beyhakī, Ebû Bekir Ahmed b. Hüseyin. es-Sünenü'l-kübrā. 10 Cilt. Haydarâbâd: Meclisü Dâirati'l-Ma ârifi'n-Nizâmiyye, 1. Baskı, 1344.

Beyhakî, Ebû Bekir Ahmed b. Hüseyin. Ma'rifetü's-sünen ve'l-āsāarr. 15. Cilt. Thk. Abdulmu'tî Emîn Kal'acî. Karaçi: Câmiatü'd-Dirâsâti'l-İslâmiyye, v.dğr., 1. Baskı, 1412/1991.

Beyhakî, Ebû Bekr Ahmed b. el-Huseyn. Delāi'lü'n-nübüvve ve ma'rifetü aḥvāli șāhibi'ş-șerī‘a. 7 Cilt. Tlk. Abdulmu'tî Kal'acî. Beyrut: Dâru'l-Kütübi'l-'İlmiyye/Dâru'r-Reyyân li'tTurâs, 1. Baskl, 1408/1988.

Bezzâr, Ebû Bekr Ahmed b. Amr b. Abdulhâllk b. Hallâd b. Ubeydullâh el-Atekî. Musnedu'lBezzār (Bahru'z-zehhhār). 18 Cilt. Thk. Mahfûzurrahmân Zeynullāh, Âdil b. Sa'd, Sabrî Abdulhâlık eş-Şâfiî. Medine: Mektebetu'l-'Ulûmi ve'l-Hikem, 1. Baskı, 1988/2009.

Buhârî, Muhammed b. İsmail. el-Cāmi'u'ș-șahịh. Riyad: Dâru's-Selâm, 2. Baskı, 1999.

Buhârî, Muhammed b. İsmail. Kitābu't-tārīhi'l-kebìr. 12 Cilt. Beyrut: Dâru'l-Kütübi'l-'İlmiyye, ts.

Coşkun, Selçuk. "Metin İnşâsının Teorik ve Uygulamadaki Bazı Problemleri Üzerine”. Bayburt Üniversitesi İlahiyat Fakültesi Dergisi 1/1 (Haziran 2015), 60-94.

Dârekutnî, Ali b. Ömer. es-Sünen. 5 Cilt. Thk. Şuayb el-Arnaût, Hasen Abdülmün'im Şelebî, Abdullatif Hırzallah, Ahmed Berhûm. Beyrut: Müessesetü'r-Risâle, 1. Baskl, $1424 / 2004$.

Dârimî, Ebû Muhammed Abdullah Abdurrahman ed-Dârimî. es-Sünen. İstanbul: Çağrı Yayınları/Dâru Sehnûn, 2. Baskı, 1413/1992.

Ebû Dâvûd, Süleyman b. el-Eş’as es-Sicistânî. es-Sünen. Kahire: Dâru İbni'l-Cevzî, 1. Baskı, $1432 / 2011$.

Elbânî, Muhammed Nâsıruddîn. Silsiletü'l-ehādīși'ż-ża 'îfe ve'l-mevżü'a ve eșeruha's-seyyiu' fi'l'ümme. 14 Cilt. Riyad: Dâru'l-Meârif, 1. Baskı, 1412/1992.

Erul, Bünyamin, “Hz. Peygamber'e Kur'ân Dışında Vahiy Geldiğini İfade Eden Rivayetlerin Tahlil ve Tenkidi", Islâmiyât 1/1 (1998), 55-72.

Hâkim, Muhammed b. Abdillah en-Nîsâbûrî. el-Müstedrek 'ale'ș-Ṣahịhaynn. 4 Cilt. Beyrut: Dâru'lKütübi'l-'ilmiyye, 1. Baskı, 1411/1990.

Hattâbî, Ebû Süleyman Hamd b. Muhammed. Me'ālimu's-sünen. 4 Cilt. Tsh. Muhammed Râğıb Tabbâh. Haleb: Matba'atu'l-İlmiyye, 1. Baskı, 1352/1933.

Hatiboğlu, Mehmed Said. Hz. Peygamber ve Kur'ân Dışı Vahiy. Ankara: Otto Yayınları, 6. Baskı, 2017.

İbn Ebî Hâtim, Ebû Muhammed Abdurrahman. Kitābu'l-cerḥi ve't-ta'dīl. Beyrut: Dâru'lKütübi'l-'ilmiyye, 1. Baskı, 1953.

İbn Ebî Hâtim, Ebû Muhammed Abdurrahman. Kitābu'l-merāsīl. Thk. Şükrullah b. Nimetillah Kûçânî. Beyrut: Müessesetü'r-Risâle, 2. Baskı, 1418/1998.

İbn Ebî Şeybe, Ebû Bekir Abdullah b. Muhammed. el-Mușannef. 21 Cilt. Thk. Muhammed Avvâme. b.y.: Dâru'l-Kıble, ts.

İbn Hacer, Şihâbüddîn Ahmed b. Ali b. Muhammed b. Ahmed Askalânî. Fetḥu'l-bārī şerḥu Șahịhi'l-Buhārīi. 8 Cilt. Beyrut: Dâru'l-Ma'rife, 1. Baskı, 2005. 
İbn Hacer, Şihâbüddîn Ahmed b. Ali b. Muhammed b. Ahmed el-Askalânî. Tehzīibu't-Tehzīib. 4 Cilt. Beyrut: Müessesetü'r-Risâle, 1995.

İbn Hacer, Ahmed b. Ali el-Askalânî. Takrību't-Tehzīib. 2. Cilt. Beyrut: Dâru'l-Kütübi'l-'İlmiyye, 2. Baski, 1415/1995.

İbn Hazm, Ebû Muhammed Ali b. Ahmed. el-Ịhkām fì uṣūli'l-ạ̣kām. 8 Cilt. Thk. Ahmed Muhammed Şâkir. Beyrut: Dâru'l-Âfâki'l-Cedîde, ts.

İbn Hibbân, Muhammed b. Ahmed Ebû Hâtim et-Temîmî el-Büstî. Kitābu'ś-sikịāt. 10 Cilt. Haydarâbâd: Müessesetü'l-Kütübi's-Sekâfiyye, 1. Baskı, 1393/1973.

İbn Hişâm, Ebû Muhammed Abdülmelik. es-Sìretü'n-nebeviyye. Thk. Cemâl Sâbit, Muhammed Mahmûd, Seyyid İbrahim. Kahire: Dâru'l-Hadîs, 1427/2006.

İbn İshâk, Muhammed. es-Sirretü'n-nebeviyye. thk. Ahmed Ferîd el-Mezîdî. Beyrut: Dâru'lKütübi'l-'İlmiyye, 1424/2004.

İbn Manzûr, Cemalüddîn Muhammed b. Mükerrem. Lisānu'l-'Arab. 6 Cilt. Thk. Abdullah Ali elKebîr, Muhammed Ahmed Hasebullah, Hâșim Muhammed eș-Şâzelî, Seyyid Ramazan Ahmed. Kahire: Dâru'l-Ma'ârif, ts.

İbn Sa'd, Muhammed b. Sa'd b. Meni' ez-Zührî. Kitābu'ț-țabakāti'l-kebīr. 11 Cilt. Thk. Ali Muhammed Ömer. Kahire: Mektebetü'l-Hancî, 1. Baskı, 1421/2001.

Kırbaşoğlu, Mehmet Hayri. İslâm Düşüncesinde Sünnet. Ankara: Fecr Yayınları, 1. Baskı, 1993.

Ma'mer b. Ebî Amr Râşid Ebû Urve el-Basrî. el-Cāmic (Abdurrezzâk es-San'ânî'nin el-Musannefi ile birlikte). 2. Cilt. Thk. Habîburrahmân el-A'zamî. Pakistan: el-Meclisü'l-İlmî/Beyrut: el-Mektebu'l-İslâmî, 2. Baskı, 1403/1983.

Mâtürîdî, Ebû Mansûr Muhammed b. Muhammed. Te’vīlātü'l-Kur'ān. 18 Cilt. Thk. Ahmed Vanlıoğlu. İstanbul: Dâru'l-Mîzân, 2005.

Mizzî, Cemâlüddîn Ebu'l-Haccâc Yusuf. Tehzīibu'l-Kemāl fi esmāi'r-ricāl. 35 Cilt. Thk. Beşşâr Avvâd Marûf. Beyrut: Müessesetü'r-Risâle, 2. Baskı, 1403/1983.

Musa b. Ukbe. el-Megāzī. thk. Muhammed Bakşîş Ebû Mâlik. el-Memleketü'l-Mağribiyye: Câmiâtu İbn Zühr, 1994.

Müslim, Ebu'l-Huseyn Müslim b. el-Haccâc. el-Cāmi 'u'ṣ-șaḥiḥ. 3 Cilt. İstanbul: Çağrı Yay. ve Dâru Sehnûn, 2. Baskı, 1413/1992.

Nevevî, Ebû Zekeriyyâ Yahyâ b. Şeref. el-Minhāc șerḥu Șahịhi Müslim b. el-Haccāc. 18 Cilt. Thk. Muhammed Beyyûmî. Kâhire: Dâru'l-Gaddi'l-Cedîd, 1. Baskı, 1429/2008.

Sancaklı, Saffet. Hadis İnkârcılı̆̆ı/Hadis Karşıtlarının İddiaları ve Cevaplar. İstanbul: Rağbet Yayınları, 3. Baskı, 2018.

Şafiî, Ebû Abdillah Muhammed b. İdrîs. er-Risāle. Thk. Abdüllatif el-Hümeym, Mâhir Yâsîn elFahl. Beyrut: Dâru'l-Kütübi'l-'Illmiyye, 2. Baskı, 2009.

Şafiî, Ebû Abdillah Muhammed b. İdrîs. el-Ümm. 8 Cilt. Beyrut: Dâru'Ma'rife, 1393.

Taberânî, Ebu'l-Kâsım Süleyman b. Ahmed. el-Mu'cemu'l-kebīr. 25 Cilt. Thk. Hamdî b. Abdülmecîd es-Selefî. Musul: Mektebetü'l-'Ulûm ve'l-Hikem, 2. Baskl, 1404/1983.

Usmani, Muhammad Taqi. The Authority of Sunnah. Karachi: Idratul Quran, ts.

Vâkıdî, Ebû Abdillah Muhammed b. Ömer. Kitābu'l-megāzī. 3. Cilt. Thk. Marsden Jones. Beyrut: Âlemu'l-Kütüb, 3. Baskı, 1966.

Zehebî, Şemsüddîn Muhammed b. Ahmed b. Osman. Siyeru a lāmi'n-nübelā. 29 Cilt. Thk. Şuayb el-Arnaût, Ali Ebû Zeyd, Muhammed Nuaym el-Araksûsî. Beyrut: Müessesetü'r-Risâle, 2. Baski, 1402/1982.

Zuhaylî, Vehbe. el-Frḳhu'l-İslāmī ve edilletuhū. 8 Cilt. Dımaşk: Dâru'l-Fikr, 2. Baskı, 1405/1985. 